\title{
Editorial
}

\section{Management of the political process}

We can define managerial behavior as a process of stating objectives and solving problems in interaction with others. Managerial behavior, as we shall see, is a process consisting of three main dimensions.

Based upon our experience in the seventies, the eighties will demand more self-awareness with respect to managerial behavior in the private organizations, public institutions, trade unions and the private and public sectors as a whole.

Especially, we shall in the eighties focus upon the following:

- Management Development,

- Management of the Development,

- Service Management,

- Management in the Public Sector,

- International Management,

- Political Management.

Political management is important because almost everybody is a member of at least one union/trade organization or some other political organization. The membership demands results for their fees.

The problem of political management is that we have not properly learned how to organize a battlefield for the political fight. Political fights are partly necessary, partly desirable, but for the moment they destroy more than is beneficial for the organization and for the society as a whole.

We have to be more conscious about how to organize this fight.

The power structure can be described by the organization of the decision process in terms of political decision variables.

Decisions for the whole can be centralized or decentralized. Decisions within a single unit may be based upon a personal power-base or upon a collective power-base.

This yields four types of power structure, as in Fig. 1(a). We shall not discuss them further in the present context.

North-Holland Publishing Company

Human Systems Management 2 (1981) 1-2
The function of the structure is to establish ends and means (objectives and activities to attain them). In terms of political decision variables, ends can be formulated according to rules of consensus (compromise, securing minority desires), or according to authority: the people in power can overrule others, the majority may decide.

Means, in this context, implies participation versus non-participation (open versus closed system).

The types of function of the decision process in terms of political behavior are given in Fig. 1(b), without further comments.

The political battlefield combines the structure and function of the decision process in terms of

\begin{tabular}{c||l|l|}
\multicolumn{2}{c|}{ Whole } \\
\cline { 2 - 3 } Decentralized & Feudalism & $\begin{array}{l}\text { Organized } \\
\text { Democracy }\end{array}$ \\
\hline \multirow{2}{*}{ Centralized } & Monarchy & $\begin{array}{l}\text { Representative } \\
\text { Democracy }\end{array}$ \\
\hline & $\begin{array}{l}\text { Personal } \\
\text { Power-Base }\end{array}$ & $\begin{array}{l}\text { Collective } \\
\text { Power-Base }\end{array}$
\end{tabular}

(a)

\begin{tabular}{c|l|l|}
\multicolumn{1}{c|}{ Ends } \\
\cline { 2 - 3 } Consensus & $\begin{array}{l}\text { Elitist } \\
\text { Power }\end{array}$ & $\begin{array}{l}\text { Democratic } \\
\text { Power }\end{array}$ \\
\cline { 2 - 3 } Overruling & $\begin{array}{l}\text { Legitimate } \\
\text { Power }\end{array}$ & $\begin{array}{l}\text { Pseudo- } \\
\text { Democratic } \\
\text { Power }\end{array}$ \\
\hline & $\begin{array}{l}\text { Non-Parti- } \\
\text { cipation }\end{array}$ \\
\hline
\end{tabular}

(b)

Fig. 1. Structure and function of the decision process in terms of political behavior; (a) Structure; (b) Function. 
political behavior. Its profile can be established by connecting the squares in Fig. 1(a) and (b).

It is up to the members of the organization itself to agree on what shape this battlefield should take.

First of all, the interested parties should agree on a set of strategic objectives as a basis for their future cooperation. This could for example be an increasing quality of life.

Next, the stakeholders should explore how to make their cake bigger and how to increase the quality of the cake as well as the distribution of it. It is necessary to discuss all three aspects and not only the last one, as is the usual argument in current political fights.

Also, the quality of the production process should be agreed upon. That is, How to make the work environments better and more human? It is our nor- mal experience that almost every organization has a potential for insight and creativity with respect to this specific dimension.

If the stakeholders agree that each one is better off if they participate in management of their own development, they will ask: What can we do together in order to satisfy our mutual interests better?

Political management is the process of organizing a battlefield, and the aim of the battle is to attain such supreme objective in the best way possible.

Political management means credibility combined with results.

Every single firm or institution should experiment with this sort of managerial activity.

Erik JOHNSEN 